\title{
Intermittent Domestic Water Supply: A Critical Review and Analysis of Causal-Consequential Pathways
}

\author{
S. E. Galaitsi ${ }^{1, *}$, Robert Russell ${ }^{2}$, Amahl Bishara ${ }^{3}$, John L. Durant ${ }^{4}$, Jennifer Bogle ${ }^{5}$ and \\ Annette Huber-Lee ${ }^{1,4}$ \\ 1 US-Center, Stockholm Environment Institute, Medford, MA 02155, USA; annette.huber-lee@sei-us.org \\ 2 Strategic Environmental Consulting, 9 Spruce Avenue, Cambridge, MA 02138, USA; \\ rr-enviroconsult@comcast.net \\ 3 Department of Anthropology, Tufts University, Medford, MA 02155, USA; amahl.bishara@tufts.edu \\ 4 Department of Civil \& Environmental Engineering, Tufts University, Medford, MA 02155, USA; \\ john.durant@tufts.edu \\ 5 Department of Urban and Environmental Policy and Planning, Tufts University, Medford, MA 02155, USA; \\ jenbogle@gmail.com \\ * Correspondence: stephanie.galaitsi@sei-us.org; Tel.: +1-617-627-3786
}

Academic Editor: Peter Coombes

Received: 27 April 2016; Accepted: 20 June 2016; Published: 30 June 2016

\begin{abstract}
Communities in many parts of the world, especially in developing countries, face obstacles in supplying continuous water to household consumers. Authorities often cite water scarcity as the cause, but we demonstrate that environmental constraints constitute only one aspect of a multi-dimensional problem. By asking what causes intermittent domestic water supply, this literature review (129 articles) identifies 47 conditions of intermittent systems and the causal-consequential pathways between them that can reinforce intermittency. These pathways span several disciplines including engineering, government administration and anthropology, and when viewed together they (1) emphasize the human drivers of intermittency; (2) suggest generalized interventions; and (3) reveal a gap in the literature in terms of meaningful categorizations of the reliability of intermittent supplies. Based on the reliability of consumers' water access, we propose three categories of intermittency - predictable, irregular, and unreliable - to facilitate comparisons between case studies and transfers of solutions.
\end{abstract}

Keywords: domestic water supply; intermittent water supply; unreliable water supply; water resources management; interdisciplinary review

\section{Introduction}

Intermittent water supply is a reality for people throughout the developing world. This paper examines conditions that encourage, enable, and sustain intermittent water supply in order to demonstrate the full scope of causes and consequences of this phenomenon. Water resource scarcity is often put forward by water suppliers as the primary explanation for demand-supply gaps [1], but our analysis demonstrates that insufficient water resources and other environmental constraints constitute only one aspect of a multi-dimensional problem. Overemphasis on natural resource constraints risks under-valuing the human drivers that often reinforce intermittent supply.

We identify and analyze conditions seen in intermittent supply systems, both as causes and consequences of intermittency. The causal-consequential pathways between them can create a "spiral of decline" [2] - a complex negative feedback loop that reinforces service intermittency. When viewed together, the conditions and the pathways among those conditions offer new insight into trends and 
possible interventions, while at the same time revealing that the terminology in the literature can be refined to more specifically characterize intermittent systems.

The word "intermittent" denotes a water supply that for periods of time is unavailable. Access to water in an intermittent system can range from predictable to unreliable, and this distinction can have serious implications for consumers. Studies of water supply in developing areas often do not clearly characterize supplies in a consistent, standardized way, rendering the lessons of a given case study or cultural analysis difficult to apply elsewhere. Nonetheless, it is possible to examine this literature in a rigorous way and to draw a set of conclusions that - when combined with a more precise definition of intermittency-will help researchers assess broader questions of social policy in communities that lack reliable and sufficient access to domestic water supplies.

Previous research has shown interrelationships between the water service delivery failures and adverse life impacts on the consumers using the water [3]. Our research examines the way in which the causes and consequences of water intermittency exist in a complex structure of interactions that affect the options available for making the transition to a continuous water supply. By compiling distinct cause-consequence pathways, our analysis identifies the conditions that both lead to and develop from water intermittency. It is a self-reinforcing system, wherein the consequences of some conditions are themselves causes of others.

This literature review considers peer-review journal articles, books and gray literature and explores all types of water intermittency affecting household supplies. In doing so, we demonstrate a spectrum of conditions that can occur under an intermittent supply regime.

\section{Methods}

In conducting our literature review, we first identified articles that directly examine intermittent domestic water supply using the Web of Science Research Guide from 1990 to April 2016. The divergent vocabulary used to describe intermittent supply regimes is itself a challenge. To gather literature for this analysis, we used the following terms and combinations thereof: intermittent domestic water, intermittent household water, reliable household water supply, intermittent water distribution system, drinking water source reliability, community water security, community water insecurity, community water distress, household water service, improved water supply, water outage, coping unreliable water supply, and irregular domestic water supply.

In reviewing the assembled references, we identified causal-consequential pathways through an examination of the case-studies we uncovered with our search. Each pathway links two conditions of intermittent supply, where one serves as the cause and the other as the consequence of the particular pathway. These pathways were not necessarily drawn from the main argument of the papers; in some instances, they were derived from the way in which a paper characterized the water intermittency problem. Together, the pathways create a structure of interactions that demonstrates the complexity of intermittent water supply.

For example, the pathway Poor system (system not maintained) $\rightarrow$ intermittent supply stems from the following citations:

"Because of an old and poorly maintained distribution system, the service is not efficient ... Low discharge and intermittent supply is one of the most serious problems of ... . water supply services." [4]

"Because of ... mechanical failures [among other relationships], water service is notoriously unreliable." [5]

Similarly, the pathway intermittent supply $\rightarrow$ access inequality is drawn from the following citations:

"Due to intuitively operated intermittent water distribution, supply times usually differ throughout the supply system. As a consequence, the supply is inequitable regarding the quantity supplied." [6]

"The application of the model confirmed the relevant negative impacts of intermittent supply, allowing some users to collect their entire daily water demand in [a] few hours, and the inequality and competition that intermittent supply generates among users." [7] 
"Most developing countries have intermittent water supply and sometimes a large quantity of water is received by only a few zones or consumers, leading to inequitable water supply." [8]

Our analysis required recognizing when studies used different terms to refer to the same condition, which we then assigned a single label. For example, the condition Suffering/Interpersonal conflict encompasses the social unease and physical hardships that consumers experience as a result of intermittent water supply. We aggregated those conditions because they cause the same consumer decision (investment in private infrastructure), and therefore can be represented as a single condition.

\section{Results}

From the articles identified by these searches, we followed citations to additional articles, gathering a total of 129 documents, including peer-reviewed articles, conference proceedings, book chapters and books that examined various aspects of intermittent water supply and consumer responses to it. The subjects of this literature span geographies, community types, and water supply infrastructure, with the latter including well water, tanker water, and piped water. Table 1 summarizes the category of reference and the source of water it primarily examined. All of these situations contribute to an understanding of the larger narrative of the challenges of intermittent water supply. Figure 1 shows the location of the 109 case studies examined in the identified articles (note that some studies compared multiple locations).

Table 1. Summary of Literature Search on Intermittent Water Supply.

\begin{tabular}{cc}
\hline Number of Studies Identified & $\mathbf{1 2 9}$ \\
\hline Empirical case studies & 109 \\
\hline Type of Article: & \\
\hline Peer-Reviewed Journal Articles & 115 \\
Conference Proceedings & 7 \\
Books & 4 \\
Book Sections $^{2}$ & 3 \\
\hline Source of Water: ${ }^{1}$ & \\
\hline Piped network water & 119 \\
Well water & 24 \\
Private water vendors & 18 \\
Other $^{2}$ & 10 \\
\hline
\end{tabular}

Notes: ${ }^{1}$ : A single article could examine communities with multiple sources of water; ${ }^{2}$ : Such as surface water (dam and river) that was collected by household members.

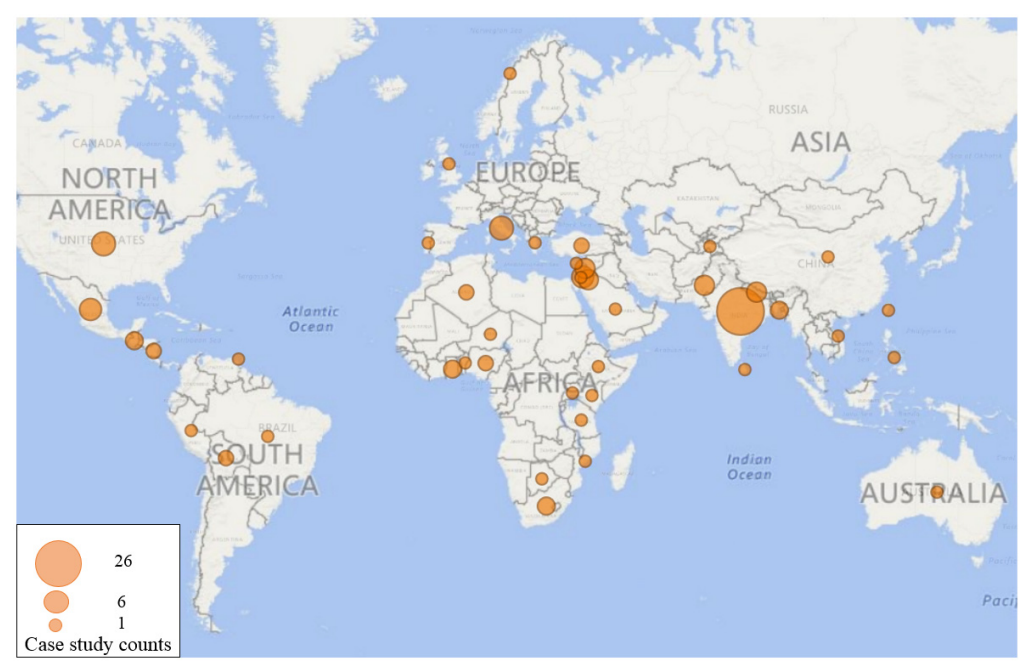

Figure 1. Geographic distribution of intermittent water case studies found in the literature [1-129]. 
The identified pathways and the conditions they connect span many disciplines, including social science, public health and engineering. We found that the disciplines represented grouped into thirteen categories in Figure 2. Author-represented disciplines in the chart are listed from the most common at the top, starting with Civil and Environmental Engineering, to least common, Information Technology. These discipline groupings emerged from reviewing the authors' affiliation as listed in the article, or in cases where that information was not available, from information about the author's educational background from other sources. The total frequency of author representation for each discipline is listed in the legend. Note that Figure 2 does not include the Santa Cruz Declaration [26] due to the large number of signatories.

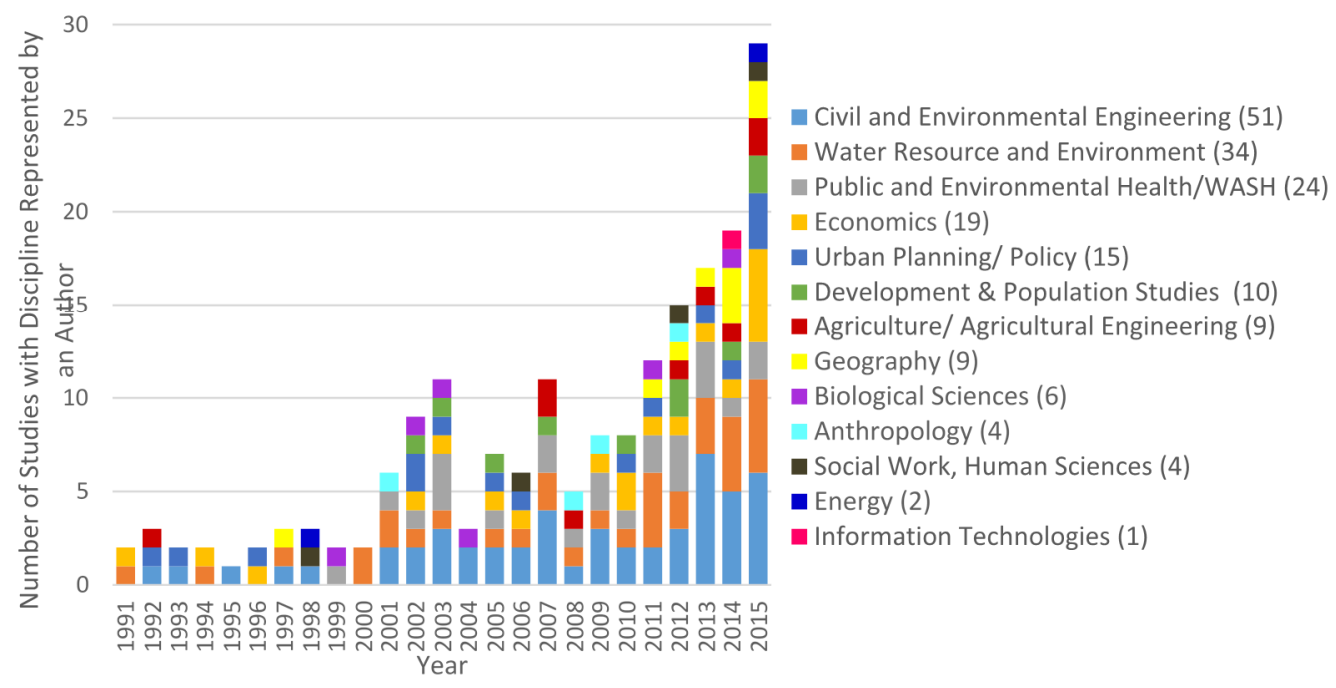

Figure 2. Disciplines represented by authors of intermittent water supply studies 1991-2015 (total number of studies $=126$; numbers in parentheses are the number of times each discipline appeared in the author lists) [1-25,27-64,66-125,127-129].

We identified a total of 106 cause-consequence pathways between 47 conditions of water intermittency. Table 2 lists each condition in alphabetical order, and the conditions that arise consequentially according to the literature, with citations provided. Each pairing constitutes a pathway. Each condition is placed in one of five categories, discussed below.

Table 2. Pathways between Conditions of Intermittent Water Supply.

\begin{tabular}{|c|c|c|}
\hline Causal Condition in Pathway & $\begin{array}{l}\text { Category of } \\
\text { Condition }\end{array}$ & Consequential Condition(s) in Pathway \\
\hline Access inequality & Capacity Constraint & $\begin{array}{l}\text { - Private investment in water infrastructure }[6,116] \\
\text { - Suffering/interpersonal conflict }[16,32,44,125] \\
\text { - Low consumer confidence/satisfaction }[116]\end{array}$ \\
\hline $\begin{array}{l}\text { Broadest network distribution } \\
\text { prioritized }\end{array}$ & Local Governance & $\begin{array}{l}\text { - Low prices [15] } \\
\text { - Water rationing by utility [107] } \\
\text { - Network stretched beyond capacity to deliver continuous } \\
\text { supply }[5,81] \\
\text { - Intermittent supply }[2,43,111,113]\end{array}$ \\
\hline Consumers overdraw & Consumer Response & - Water losses/less water in system $[32,48]$ \\
\hline
\end{tabular}


Table 2. Cont.

\begin{tabular}{|c|c|c|}
\hline Causal Condition in Pathway & $\begin{array}{l}\text { Category of } \\
\text { Condition }\end{array}$ & Consequential Condition(s) in Pathway \\
\hline $\begin{array}{l}\text { Coping mechanisms among the } \\
\text { most impoverished are not } \\
\text { observed or understood }\end{array}$ & Local Governance & $\begin{array}{l}\text { - Politicians do not believe the poor are willing to pay for } \\
\text { water }[94,127]\end{array}$ \\
\hline Demand-supply gap widens & Large-Scale Trend & - Water rationing by utility [7] \\
\hline Development & Large-Scale Trend & - Increased water demand [37] \\
\hline Electricity blackouts & Capacity Constraint & - Intermittent supply $[33,87,107,111]$ \\
\hline $\begin{array}{c}\text { Funders prefer new construction } \\
\text { over improvements }\end{array}$ & Local Governance & - Water utility has insufficient funds to perform job [28] \\
\hline $\begin{array}{l}\text { Government corruption/power } \\
\text { structures that prioritize } \\
\text { privilege }\end{array}$ & Local Governance & $\begin{array}{l}\text { - Low consumer confidence/satisfaction }[128] \\
\text { - Policies do not address intermittency }[26,88]\end{array}$ \\
\hline Higher costs to run system & Capacity Constraint & - Poor water utility service $[87,107]$ \\
\hline $\begin{array}{l}\text { Hydrological regime changes } \\
\text { (e.g., climate change, } \\
\text { anthropomorphic change) }\end{array}$ & Large-Scale Trend & - Demand-supply gap widens $[6,7,37,114]$ \\
\hline $\begin{array}{c}\text { Inadequate water delivered to } \\
\text { households }\end{array}$ & Capacity Constraint & - Suffering/interpersonal conflict $[62,127]$ \\
\hline Increased population & Large-Scale Trend & - Increased water demand $[4,18,25,66,114]$ \\
\hline Increased water demand & Large-Scale Trend & $\begin{array}{l}\text { - Demand-supply gap widens }[32,105] \\
\text { - Network expansions beyond original plan/service } \\
{[22,66,114]} \\
\text { - Network stretched beyond capacity to deliver continuous } \\
\text { supply [107] }\end{array}$ \\
\hline Insufficient metering & Capacity Constraint & $\begin{array}{l}\text { - Poor utility data management [123] } \\
\text { - Low profit [81] }\end{array}$ \\
\hline Intermittent water supply & Capacity Constraint & $\begin{array}{l}\text { - Access inequality [6-8] } \\
\text { - Low consumer confidence/satisfaction }[98,111] \\
\text { - Users frame their activities by water access }[27,101,128] \\
\text { - Private investment in water infrastructure } \\
{[6,15,40,42,48,53,56,81,127]} \\
\text { - Inadequate water delivered to households }[30] \\
\text { - Time costs to consumers }[6,53,70,87,111,127] \\
\text { - Higher costs to run system }[127] \\
\text { - Pressure surges in system }[114] \\
\text { - Relying on personal networks to obtain water }[25,27,65]\end{array}$ \\
\hline Leaks in system & Capacity Constraint & $\begin{array}{l}\text { - Water losses/less water in system }[1,107] \\
\text { - Poor water quality }[4,45,49,52,81,108,127]\end{array}$ \\
\hline $\begin{array}{l}\text { Less willingness to pay for } \\
\text { municipal water }\end{array}$ & Consumer Response & $\begin{array}{l}\text { - Private water vendors [50] } \\
\text { - Low utility profit/cost recovery [98] }\end{array}$ \\
\hline Local resource depletion & Local Governance & - Water losses/less water in network $[25,32,107]$ \\
\hline
\end{tabular}


Table 2. Cont.

\begin{tabular}{|c|c|c|}
\hline Causal Condition in Pathway & $\begin{array}{l}\text { Category of } \\
\text { Condition }\end{array}$ & Consequential Condition(s) in Pathway \\
\hline $\begin{array}{l}\text { Low consumer } \\
\text { confidence/satisfaction }\end{array}$ & Consumer Response & $\begin{array}{l}\text { - Less willingness to pay for municipal water } \\
{[2,5,33,76,87,98,107,115,120]} \\
\text { - Private investment in water infrastructure [116] }\end{array}$ \\
\hline Low prices & Local Governance & $\begin{array}{l}\text { - Water conservation not encouraged }[76,83,128] \\
\text { - Low utility profit/cost recovery (assumed) }\end{array}$ \\
\hline Low utility profit/cost recovery & Capacity Constraint & $\begin{array}{l}\text { - Politicians do not believe the poor are willing to pay [33] } \\
\text { - Water utility has insufficient funds to perform job } \\
{[87,118,129]}\end{array}$ \\
\hline $\begin{array}{l}\text { Network expansions beyond } \\
\quad \text { original plan/service }\end{array}$ & Capacity Constraint & $\begin{array}{l}\text { - Network stretched beyond capacity to deliver continuous } \\
\text { supply [6] } \\
\text { - Poor system conditions [6] }\end{array}$ \\
\hline $\begin{array}{l}\text { Network stretched beyond } \\
\text { capacity to deliver continuous } \\
\text { supply }\end{array}$ & Capacity Constraint & - Water rationing by utility [assumed] \\
\hline $\begin{array}{l}\text { Policies do not address } \\
\text { intermittency }\end{array}$ & Local Governance & $\begin{array}{l}\text { - Low prices }[5,33,91,118,128] \\
\text { - Poor system conditions }[33,62,127] \\
\text { - Local resource depletion }[128] \\
\text { - Water utility has insufficient funds to perform job }[20,120] \\
\text { - Access inequality }[26,28,96,107]\end{array}$ \\
\hline $\begin{array}{l}\text { Political misjudgments of } \\
\text { progress indicators }\end{array}$ & Local Governance & $\begin{array}{l}\text { - Broadest network distribution prioritized [19] } \\
\text { - Funders prefer new construction over improvements [28] }\end{array}$ \\
\hline $\begin{array}{l}\text { Politicians do not believe the } \\
\text { poor are willing to pay }\end{array}$ & Local Governance & $\begin{array}{l}\text { - Low prices }[15,33,129] \\
\text { - Intermittent supply }[15]\end{array}$ \\
\hline Poor utility data management & Capacity Constraint & $\begin{array}{l}\text { - Policies do not address intermittency }[6,37] \\
\text { - Coping mechanisms among the most impoverished are } \\
\text { not observed or understood [127] } \\
\text { - Network expansions beyond original plan/service [6] }\end{array}$ \\
\hline Poor system conditions & Capacity Constraint & $\begin{array}{l}\text { - Insufficient metering }[29] \\
\text { - Water losses/less water in system }[76,83,88] \\
\text { - Intermittent supply }[4,5] \\
\text { - Pressure surges in system }[6] \\
\text { - Access inequality }[6,107,113] \\
\text { - Leaks in system }[6,13,71]\end{array}$ \\
\hline Poor water quality & Health & $\begin{array}{l}\text { - Suffering/Interpersonal conflict }[9,33,45] \\
\text { - Less willingness to pay for municipal water [51] }\end{array}$ \\
\hline Poor water utility service & Capacity Constraint & $\begin{array}{l}\text { - Intermittent supply }[15,71,77,111] \\
\text { - Utility mismanagement of resources [7] } \\
\text { - Insufficient metering [33] }\end{array}$ \\
\hline
\end{tabular}


Table 2. Cont.

\begin{tabular}{|c|c|c|}
\hline Causal Condition in Pathway & $\begin{array}{l}\text { Category of } \\
\text { Condition }\end{array}$ & Consequential Condition(s) in Pathway \\
\hline Pressure surges in system & Capacity Constraint & $\begin{array}{l}\text { - Poor water quality }[43,73,81,83,114] \\
\text { - Leaks }[13,33] \\
\text { - Poor system condition }[6,49]\end{array}$ \\
\hline $\begin{array}{l}\text { Private connections/illegal } \\
\text { connections }\end{array}$ & Consumer Response & $\begin{array}{l}\text { - Network stretched beyond capacity to deliver continuous } \\
\text { supply [6] } \\
\text { - Water losses/less water in system }[22,88] \\
\text { - Poor utility data management }[76,123] \\
\text { - Poor water quality [43] }\end{array}$ \\
\hline $\begin{array}{l}\text { Private investment in water } \\
\text { infrastructure }\end{array}$ & Consumer Response & $\begin{array}{l}\text { - Access inequality [7] } \\
\text { - Less willingness to pay for municipal water }[12,15,120] \\
\text { - Private connections/illegal connections }[6,34,53] \\
\text { - Water utility has insufficient funds to perform job } \\
{[15,87,127,128]} \\
\text { - Time costs to consumers }[33,64,127] \\
\text { - Private storage }[6,28,33] \\
\text { - Private water vendor purchases }[53,65,67,73] \\
\text { - Private wells }[6,18,67,73,128]\end{array}$ \\
\hline Private storage & Consumer Response & $\begin{array}{l}\text { - Poor water quality }[45,46,55,110] \\
\text { - Water is wasted by consumers }[23,35,70,81,128] \text { although } \\
\text { the opposite has been found under specific circumstances } \\
{[18,47]} \\
\text { - Pressure surges in system }[6,13,48] \\
\text { - Consumers overdraw }[2,23,35,50,76,114]\end{array}$ \\
\hline Private water vendors & Consumer Response & $\begin{array}{l}\text { - Government corruption/power structures that prioritize } \\
\text { privilege [88] } \\
\text { - Low utility profit/cost recovery (assumed) }\end{array}$ \\
\hline Private wells & Consumer Response & $\begin{array}{l}\text { - Local resource depletion }[69,123] \\
\text { - Poor water quality }[90]\end{array}$ \\
\hline $\begin{array}{l}\text { Relying on personal networks to } \\
\text { obtain water }\end{array}$ & Consumer Response & - Suffering/interpersonal conflict [27] \\
\hline Suffering/Interpersonal conflict & Consumer Response & - Private investment in water infrastructure [27] \\
\hline Time costs to consumers & Consumer Response & - Suffering/interpersonal conflict $[14,53,81]$ \\
\hline $\begin{array}{l}\text { Users frame their activities by } \\
\text { water }\end{array}$ & Consumer Response & - Suffering/interpersonal conflict $[27,53,128]$ \\
\hline $\begin{array}{l}\text { Utility mismanagement of } \\
\text { resources }\end{array}$ & Capacity Constraint & - Water losses/less water in system [107] \\
\hline $\begin{array}{l}\text { Water conservation not } \\
\text { encouraged }\end{array}$ & Local Governance & $\begin{array}{l}\text { - Demand-supply gap widens [83] } \\
\text { - Water is wasted by consumers [83] }\end{array}$ \\
\hline Water is wasted by consumers & Consumer Response & - Water losses/less water in system [83] \\
\hline $\begin{array}{l}\text { Water losses/less water in } \\
\text { system }\end{array}$ & Capacity Constraint & $\begin{array}{l}\text { - Demand-supply gap widens }[16] \\
\text { - Water rationing by utility }[21,49,53,69,128]\end{array}$ \\
\hline
\end{tabular}


Table 2. Cont.

\begin{tabular}{ccl}
\hline Causal Condition in Pathway & $\begin{array}{c}\text { Category of } \\
\text { Condition }\end{array}$ & \multicolumn{1}{c}{ Consequential Condition(s) in Pathway } \\
\hline Water rationing by utility & Local Governance & - Intermittent supply $[2,7,21,99]$ \\
\hline $\begin{array}{c}\text { Water utility has insufficient } \\
\text { funds to perform job }\end{array}$ & Capacity Constraint & $\begin{array}{l}\text { - Poor utility data management (assumed) } \\
\text { - Poor system conditions }[20,87,111,120]\end{array}$ \\
& & - Poor water utility services $[23,47,48]$ \\
\hline
\end{tabular}

For example, in the first row of Table 2, the condition access inequality is in the category Capacity Constraint. The literature suggests that, when present, access inequality has three consequences: consumers invest in private water infrastructure, consumers experience suffering and interpersonal conflict, and there is low consumer confidence or satisfaction with the water supply system. Access inequality is also listed in Table 2 four times as a consequence of other conditions: intermittent water supply; policies do not address intermittency; poor system conditions; and private investment in water infrastructure. This demonstrates that access inequality is both a cause and consequence of the condition private investment in infrastructure, serving as an example of the reinforcing nature of the conditions of intermittent water supply.

Causes of each condition listed in Table 2 can be found by tracing backwards in the table, i.e., finding the condition in the "consequence" column. All conditions listed in the cause column are also consequences of intermittent supply with the exception of five conditions: increased population, hydrological regime changes, electricity blackouts, political misjudgments of progress indicators, and development. These causes are viewed as external to the water intermittency problem, so they are inputs, not reinforcers.

Although we found 102 cause-consequence pathways in the literature, we list 106 in total. The four additional pathways connect closely related conditions that, based on our review, frame separate pathways that, while not specifically named in the literature, should be recognized as distinct elements in order to approach a more complete understanding of the causal processes at work in this area. They are:

\section{Low prices $\rightarrow$ low utility profit/cost recovery \\ Network stretched beyond capacity $\rightarrow$ water rationing by utility \\ Water utility has insufficient funds to perform job $\rightarrow$ poor data management \\ Private water vendors $\rightarrow$ low utility profit/cost recovery}

This interdisciplinarity is also evident in the pathways we identified and the conditions they connect. To more effectively explore the interactions among the disciplines, we designated each condition as being affiliated with one of the five categories: large-scale trends, local governance, capacity constraints, consumer response, and health. These categories were chosen because the degree of overlap between them is minimal. We excluded economics as a category, for example, because of its high degree of overlap with governance and engineering. We define these categories as follows:

Large-Scale Trends: Forces beyond the political sphere that operates at the scale of the water network. Large-scale trends include population growth, increased per capita water demand that accompanies rising standards of living, and climate change. They tend to be the results of accumulated decisions on a very large scale (five conditions).

Local Governance: Decisions or priorities at the water supply network level. Those controlling water supply may be city or regional authorities, depending on the size of the network. Here, analytic approaches tend to focus in the fields of governance, urban planning, or other social sciences (11 conditions). 
Capacity Constraints: Capacity limitations of the network or network management, whether physical, professional, or financial. Many of these conditions encompass engineering constraints like leaks, pressure problems, and a network stretched beyond capacity. Many of these issues are considered through the disciplines of engineering, politics, and economics (17 conditions).

Consumer Response: Consumer reactions that are outside the direct influence of policy because they represent individual, disaggregated consumer decisions. Such disciplines as anthropology, sociology, economics, and psychology help describe and analyze these processes (13 conditions).

Health: Impacts affecting human health. There is only one condition in this category, water quality. It has received an enormous amount of attention in the literature because of its far-reaching implications for disease vectors, and human morbidity and mortality. Within the literature, this issue has the attention of the public health sector (one condition).

The Capacity Constraint, Consumer Response, and Local Governance categories, sequentially, have the highest number of conditions.

The interchange among these broad categories can be examined through the pathways themselves. A pathway leading from a Local Governance condition to a Capacity Constraint condition is an interdisciplinary pathway because the conditions in one domain (acting as a cause) are encouraging one or more conditions (acting as consequences) in another.

Table 3 aggregates the conditions in Table 2 by category to show the collective interactions among them. The last column and the last row show the percentage of pathways whose causes lie within the category listed in the row or column (respectively), but whose consequence or consequences lie in another category. Exclusively inter-category information is italicized, and totals are bolded.

All the pathways leading to and from the single Health condition (poor water quality) are interdisciplinary. The conditions aggregated in the Large-Scale Trend category display the lowest percentage of interdisciplinary causes because the category itself defines them as causes external to the system, rather than resulting from it. For the remaining three categories, however, Table 3 shows that the conditions aggregated in each of those categories-capacity constraints, consumer response, and local governance-are consequences of conditions in other categories between $41.2 \%$ and $46.4 \%$ of the time. This demonstrates the importance of interdisciplinary research; research too narrowly confined to a single discipline could miss nearly half of the underlying causes within these three categories. The category Consumer Response has the highest rate (46.4\%) of occurring as consequence of pathways that originate in another discipline.

The last column of Table 3 calculates the percentage of interdisciplinary pathways, this time organized by cause. Again, the Health category is completely interdisciplinary. The remaining categories vary in the rate at which they cause conditions in other categories. Causes included within Capacity Constraint conditions have the lowest percentage of interdisciplinary consequences (36.4\%). Consumer Responses and Large-Scale Trends cause interdisciplinary consequences 50\% of the time. The highest percentage of consequences in other categories is in Local Governance $(55.5 \%)$. This analysis suggests that studies lacking interdisciplinary approaches risk overlooking the consequences of a variety of system conditions. With respect to Local Governance, they would capture fewer than half of the consequences of relevant decisions. 
Table 3. Counts of pathways between categories.

\begin{tabular}{|c|c|c|c|c|c|c|c|c|}
\hline \multirow[b]{2}{*}{ Causes } & \multicolumn{6}{|c|}{ Consequences } & \multirow{2}{*}{$\begin{array}{c}\text { Total Consequential } \\
\text { Pathways }\end{array}$} & \multirow{2}{*}{$\begin{array}{l}\text { \% Inter-Category } \\
\text { Consequences }\end{array}$} \\
\hline & $\begin{array}{l}\text { Capacity } \\
\text { Constraints }\end{array}$ & $\begin{array}{l}\text { Consumer } \\
\text { Response }\end{array}$ & $\begin{array}{c}\text { Large-Scale } \\
\text { Trend }\end{array}$ & Health & Local Governance & Inter-Category Total & & \\
\hline Capacity Constraints & 28 & 9 & 1 & 2 & 4 & 16 & 44 & 36.4 \\
\hline Consumer Response & 10 & 15 & & 3 & 2 & 15 & 30 & 50.0 \\
\hline Large-Scale Trend & 3 & & 4 & & 1 & 4 & 8 & 50.0 \\
\hline Health & & 2 & & & & 2 & 2 & 100.0 \\
\hline Local Governance & 9 & 2 & 1 & & 10 & 12 & 22 & 55.5 \\
\hline Inter-Category Total & 22 & 13 & 2 & 5 & 7 & 47 & & \\
\hline Total Causal Pathways & 50 & 28 & 6 & 5 & 17 & & & \\
\hline$\%$ Inter-category causes & 44.0 & 46.4 & 33.3 & 100.0 & 41.2 & & & \\
\hline
\end{tabular}


We also analyzed the information in Table 2 to determine whether the causal-consequential pathways we found can help to identify conditions that can be targeted for intervention. We hypothesized that targeting a condition with few causes but many consequences might yield far-reaching results because a change in a single cause could reverberate across many consequences. We identified such conditions by examining the ratio of causes and consequences for a given condition, which we call the influence ratio:

$$
\text { Influence Ratio }=\frac{\text { Number of Consequences of Condition }}{\text { Number of Causes of Condition }}
$$

Figure 3 shows the distribution of these ratios ranged between 0.16 and 4 . For these calculations, we do not consider the five conditions that do not have causes in Table 2 (hydrological changes, development, increased population, electricity blackouts and political misjudgments of progress) because those are already evident places for intervention and are external to reinforcement.

Distrubtion of Influence Ratios for Intermittency Conditions

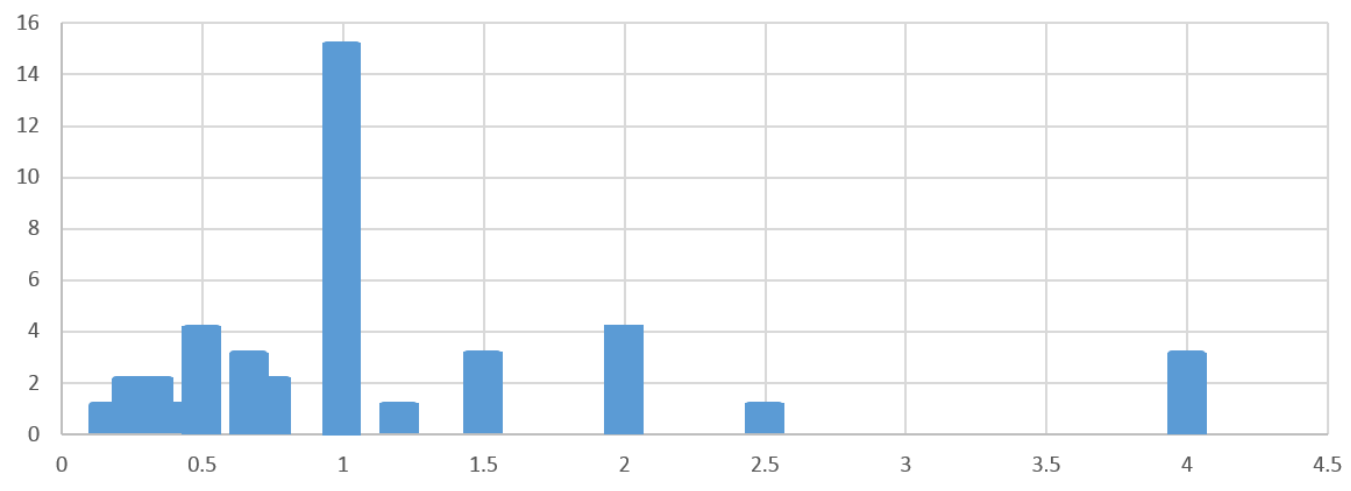

Figure 3. Distribution of Influence Rations of Intermittency Conditions. The most common ratio (15 counts) was unity (1), twelve ratio counts were $>1.0$, and sixteen were $<1$.

Figure 3 shows that there are three conditions with an influence ratio of 4 , and an additional condition with an influence ratio of 2.5. These conditions have relatively few causes and many consequences. Thus, changing those conditions will affect the greatest number of consequences and pathways in intermittent water systems.

Table 4 shows the conditions. Two out of the top four influential conditions are within the category of Local Governance. The remaining two conditions are within the Consumer Responses category. We will consider each of the four influential conditions below. Table 4 also shows the cause(s) of each influential condition, since these could also be targeted for intervention as a way to affect as many consequences as possible.

Table 4. Influential Conditions and their Causes.

\begin{tabular}{cccccc}
\hline Influential Condition & Ratio & $\begin{array}{c}\text { Category of Influential } \\
\text { Condition }\end{array}$ & $\begin{array}{c}\text { Condition(s) Acting as Causes } \\
\text { of Influential Condition }\end{array}$ & $\begin{array}{c}\text { Category of Causal } \\
\text { Condition }\end{array}$ \\
\hline $\begin{array}{c}\text { Broadest network } \\
\text { distribution prioritized }\end{array}$ & 4 & Local Governance & $\begin{array}{c}\text { Political misjudgments of } \\
\text { progress indicators }\end{array}$ & Local Governance \\
$\begin{array}{c}\text { Private connections/illegal } \\
\text { connections } \\
\text { Private storage }\end{array}$ & 4 & Consumer Response & Private investment in water & Consumer Response \\
infrastructure & Poor data management & Capacity Constraint \\
$\begin{array}{c}\text { Policies do not address } \\
\text { intermittency }\end{array}$ & 4 & Local Governance & $\begin{array}{c}\text { Government corruption/power } \\
\text { structures that prioritize } \\
\text { privilege }\end{array}$ & Local Governance \\
\hline
\end{tabular}


Of the conditions that cause the influential conditions, two of the four are also Local Governance, with one condition each within Consumer Response and Capacity Constraints. We also note that two of the influential conditions stem from a single cause: private investment in water infrastructure.

The results of this examination of influential conditions suggest that, although environmental water scarcity contributes to intermittent service, human conditions rank large in reinforcing the system.

\section{Discussion}

This analysis offers a novel view of the problem of water intermittency: Large-Scale Trends may prompt water rationing where there was none, but they do not play a major role in reinforcing intermittent water supply. Rather, those that are anthropogenic and that exhibit few causes and many consequences - in other words, the influential conditions-can be understood as the system's crucial drivers, and hence the loci for targeted intervention, even in the presence of other contributors. This is also supported by other research conclusions in the general field of water scarcity: better management can mitigate adverse natural conditions to provide a more reliable water supply to consumers.

Below we provide a more detailed view of each influential condition, as described in the literature. We discuss how the pathway leading to it might be broken, as well as whether it should be.

Broadest network distribution prioritized: Prioritizing broad distribution means trying to connect as many residents as possible to the water network. "Serving the last mile" can be complicated by socio-political issues such as secure land tenure or steady income [130], but has its basis in equity when planners choose to provide water to as many people at the lowest prices possible $[2,5,113]$. However, researchers have found that prioritizing broad distribution can cause water rationing [107], low prices [15], network stretch [81] and, generally, intermittent supply [2,43,111,113]. Unfortunately, the priority of broad delivery compromises service to individual households and produces consequences, such as household water storage, which in turn help to further entrench the intermittent water supply regime. Furthermore, although piped water access is increasing faster worldwide wide than other improved water sources, intermittent water supply may become more common due to underinvestment in infrastructure [73].

This is not inevitable: network expansions can be implemented in tandem with policies (such as pricing) and careful engineering (such as new pipes emanating from the source, rather than connected to smaller periphery pipes) that together create conditions that allow everyone to be served continuously, as if it had been a larger network designed all together originally. However, this requires significantly more political will to implement, which may or may not exist.

Our literature review found only one cause related to prioritizing broad distribution, referred to here as political misjudgments of indicators of progress. As one study put it, "the presence of a piped water system, regardless of its reliability or water quality, may give the impression to government agencies or non-governmental organizations that water needs are being met and no further investment is required" [19]. In other words, broad network distribution may look good on paper, but installing pipes does not guarantee that water will be available to fill them. Political misjudgments regarding indicators of progress is one of five conditions that is not a consequence of another condition on our list. We placed this condition in the category of Local Governance rather than in Large-Scale Trends because options exist to address this condition at the local level. When formulating projects for urban centers, development agencies such as the World Bank could specifically consider the quality of service. In the absence of this metric, the benefits of water network access could be significantly overstated.

Private connection: When households have been bypassed or insufficiently served by the public water network, residents may take matters into their own hands by privately connecting to the existing network. In many developing countries, use of non-revenue water (NRW) — water lost from infrastructure-can be as high as 50\% [54]. Planners estimate that half the missing water is caused by leaks, with the other half caused by private, and often illegal, connections. Private connections further stretch the network [6] and the number of people it can adequately serve. This contributes to 
water loss from the network [22,88]; poor data management on the part of the utility, which is unable to track where the water goes [76,123]; and poor water quality [43]. Private connections are often the end result of consumers' individual decisions make private investments in obtaining water [6,34]. One way to avoid private connections would be to provide adequate connections to households in the network area.

Intervening to address private connections resembles the intervention suggested for problems that stem from broad network distribution—specifically, striving for a balance between network expansion and network service. The underlying issue with private connections remains consumer desire to exercise more control over water access. As recent research suggests [50], consumer focus on private water security is based on subjective perceptions. In an intermittent system, consumer insecurity could be the last symptom to be resolved, given that perceptions can be slow to fade. Private connections are a consequence of households' private investment, a characteristic further explored in the influential characteristic private storage.

Private storage: Private storage consists of household storage tanks that supply water when the system is not running. This is an extremely important coping mechanism for households without continuous water supply as it allows them to better manage their resources and mimic continuous water delivery. Private storage is a consequences of residents' private investment in infrastructure [6,33]. Nevertheless, private storage causes poor water quality $[46,55,110]$, pressure surges in the system $[13,48]$, and consumer overdraw $[2,23,35,50,76,114]$. Additionally, some authors found that private storage wastes water $[23,35,70,81,128]$, while others found that in systems with more reliable supply, water storage did not result in more water use [18,47]. This difference relates to the extent to which consumers need to account for risk aversion and supply security in their water supply [50], and will be discussed further below.

It may be unwise to implement measures that prevent water storage, because storage is often crucial for household water security. However, steps can be taken to disrupt the negative consequences of stored water, including routine testing and chlorination to make sure the water is safe to drink, and monitoring water tank float valves to ensure that stored water does not overflow.

Policies that do not address intermittency: Certain policies and political prioritizations from a variety of policy systems can reduce the network's ability to supply continuous water, and may further entrench intermittent supply and its negative conditions. Causes of such policies include poor data management $[6,37]$ that prevents planners from fully understanding their system and government corruption that sabotages efforts to improve supply [88]. Government corruption includes water management choices that privilege some citizens over others. Scarcity is not always a natural condition, but can be imposed on a population within the context of existing socio-political and institutional processes [82]. This can result in supply systems that exclude certain (often disenfranchised) populations in favor of supplying the powerful and privileged [26]. Such manifestations of power can appear on a grand scale-for example, enshrined in international agreements, as has been argued is the case regarding Article 40 of the Oslo Accords between Israel and the Palestine Liberation Organization [131] — or on a smaller scale, for example by state policies that do not provide water to communities outside the formal land tenure system [11]. We will further explore the issue of equity in the discussion section below.

Policies that do not address intermittency can create or exacerbate access inequality $[26,28,96,107]$, whether due to a desire to reinforce existing power structures or a misunderstanding of the operation of an intermittent system. Without appropriate policies, the system can fall into disrepair $[33,62,127,128]$, which itself causes access inequality $[6,107,113]$ by lowering service for some consumers. Policies can include efforts to support equity: water utilities may sell water at low prices $[33,118,128]$ to make water accessible to the poor, despite the high coping costs intermittent water entails in the absence of sufficient service [5]. Certain policies can encourage resource depletion-for instance, allowing the over-pumping of aquifers [128]. Finally, policies can undermine the utility or institution that supplies the water, leading to insufficient funding to perform its job $[20,120]$. 
Because the condition policies that do not address intermittency has two inputs instead of one (poor data management and government corruption/power structures that prioritize privilege), it could be more difficult to propose an encompassing intervention, especially because the each input may produce different policies. Certainly, better data management and information would help policymakers to implement policies that ensure that the system will be able to function and that utilities will recover costs. However, where government corruption or the privileging of one population over another is a significant factor in undermining sound water management, improved data management may have a limited impact.

We note that the four influential conditions are the result of local governance and consumer response to adverse situations. As starting points for interventions, these reinforcing influential conditions can be anticipated and managed (on the part of consumer response) or avoided (on the part of local governance) in ways that improve the water situation. As researchers before us have stated, a major cause of intermittent water supply is human activity, given that the primary barriers to continuous service are organizational and institutional [127,132].

The results of the influence ratio analysis demonstrate a fundamental tension between providing broader service and providing continuous service. The provision of broad water access for additional consumers can cause diminished supply service for existing customers, and likely inadequate service for the new consumers who tend to appear at network edges. The conditions in Table 2 show the many costs of intermittent water, including those to the infrastructure and the management system, as well as to consumers themselves. Intermittent supply degrades infrastructure and imposes additional management responsibilities [34].

The reliability of water supply greatly affects the consumer experience, although many studies on intermittency do not provide sufficient information to assess reliability. The assumption that water access should have priority over water supply reliability is evident in the United Nations Sustainable Development Goals [133]. Goal 6 (Water) advocates that providers "ensure access to water and sanitation for all." This contrasts with Goal 7 (Energy), which underlines reliability in its call to "ensure access to affordable, reliable, sustainable and modern energy for all." In other words, when it comes to water, reliability is an underutilized or missing metric in evaluating the welfare of the many communities around the world that have only intermittent access to water supplies.

The terminology for water intermittency is not standardized. Terms referring to intermittent water supply include irregular, unreliable, outages and scarcity, inadequate supply and poor supply. But these terms are not used consistently. For example, one researcher describes intermittent water arriving during a $24 \mathrm{~h}$ period is an unreliable supply [116], although for [34], water arriving for less than $24 \mathrm{~h}$ a day (but within a given $24 \mathrm{~h}$ period) is intermittent. Others define intermittency as water arriving at intervals of hours, days, or weeks $[21,35]$. While some studies are very clear about the service conditions [115], many studies do not provide enough information to characterize water delivery service. For a consumer, the interval of water delivery and the reliability of that interval matter greatly $[44,50,125]$, yet most studies use one of the above terms without precisely defining it or describing the relevant water delivery regime. This creates ambiguities in discussing aspects of intermittent water supply that may conflate the experiences of communities that in fact vary widely, while discouraging comparisons among others that are similar.

It is worth noting that the lack of standard terminology here to some extent may reflect the amorphous nature of the problem itself. Intermittency can take many forms across time and space. There are annual patterns of availability, with water supply reliable in one season and less predictable in others. Over time, a community's water access may shift as populations grow, or as infrastructure decays or is replaced; water availability may also fluctuate due to natural inter-annual variability. Water access can vary between neighborhoods on the same network, or between floors of the same building [128]. This type of information greatly influences consumer experience, yet can be lost when terms are imprecisely defined or well-defined terms are imprecisely matched to facts in the field. Even as we work toward a more consistent terminology, it is important to be attuned to spatial and 
temporal changes in water access. This type of variability suggests the importance of ethnographic and other social scientific approaches to understanding problems arising from water intermittency.

We posit that a tipping point exists in which the benefits of connection to public water supply are outweighed by the costs of service unreliability. The level of water service intermittency affects the level of community hardship and can signal that further expanding a given network will not provide additional benefit. The conditions and pathways identified in Table 2 may vary depending on reliability level. The literature revealed, for example, that water is more likely to be wasted if supply is unreliable. Other conditions, such as low consumer confidence/satisfaction, may exist only where reliability is low, however, this distinction did not appear.

This lack of differentiation in the literature hinders informed analyses of the systems under examination. Though authors have referenced scales of water security/insecurity [50,65], definitions do not yet exist for the spectrum of intermittent supply and have been called for elsewhere in the literature [75]. Specific definitions will better permit the characterization of individual systems, comparisons between case studies, and the generalization of successful solutions.

We propose three definitions, listed from least disruptive in consumers' lives to most disruptive: Predictable intermittency, irregular intermittency, and unreliable intermittency.

1) Predictable Intermittency: supply characterized by water shut-offs that occur generally within a predictable and anticipated schedule, and with relatively constant water pressure during each delivery. The schedule can be on time scales of days or longer. With sufficient water storage, intermittent supply can resemble continuous supply.Example: Neighborhood A receives water between 7:00 and 11:00 A.M. every day, and Neighborhood B receives water on Mondays, Wednesdays and Saturdays between 1:00 and 9:00 P.M. Rooftop storage tanks hold sufficient water to ensure that the taps in the house will always run.

2) Irregular Intermittency: intermittent supply arriving at unknown intervals within short time periods of no more than a few days. Consumers can expect to receive a certain quantity of water within the unit time frame, although they cannot anticipate precisely when the water will arrive. With appropriate storage, irregular intermittency can resemble continuous supply, but requires more attention from household residents, costing them their time.Example: Neighborhood C receives 800 liters/household/day, and Neighborhood D receives 1200 liters/household/week. The rooftop storage tanks in both neighborhoods hold water to ensure that the taps in the house will always run, but residents must sometimes get up at night or be at home during the day to turn on pumps while water is running through the supply pipes.

3) Unreliable Intermittency: intermittent supply characterized by uncertain delivery time and the risk of insufficient water quantity, often exacerbated by limited storage and long periods of non-delivery. Delivery is inconsistent and the consumer must make choices under uncertainty, requiring greater behavioral, emotional and physical defenses against to cope with shortages. Intermittent supply with inconsistent water pressure may manifest as unreliable supply.Example: In Neighborhood E, the water came for two hours a week ago, and no one knows when it will come again. The residents are depleting the reserves in their water storage, and will soon need to decide whether invest in supplemental sources from private vendors, which are much more expensive, or hope that the water will come. Sometimes their taps run dry. "The greatest problems may be felt when discontinuity is frequent, but very unpredictable." [57].

Investigating these definitions within case studies could be a priority area for future research. Understanding the differences in intermittency allows us to draw specific conclusions regarding the costs of intermittency, listed below.

Predictable intermittency does not mean insufficient household supply: Though water rationing in situations of scarcity is often used as justification for intermittent supply, in many situations it does not reduce water consumption, which is a function of users' habits and socio-economic levels [7]. It provides a temporal change in water access, because water must now be stored. But if enough 
water is delivered and consumers have sufficient storage, their consumption may not be affected at all; indeed, it can resemble continuous supply. Predictable intermittency can be the case for consumers near distribution points, even though users elsewhere in the system may not enjoy this advantage. We hypothesize that predictable intermittency does not apply to many of the conditions found in our analysis, such as inadequate water, suffering and conflict, decreased willingness to pay, and low consumer confidence/satisfaction. The consumers are engaged in the system and ready for it to improve. Predictable intermittency will require an entirely different approach from that required for unreliable intermittency, where users may distrust the supplier and have little faith in prospects for improvement.

Inadequate service spurs consumers to disengage from the network as they invest in private storage and alternative sourcing. Investments of some type are required for all three forms of intermittent water supply, but investment is especially important where supply is unreliable. Consumers' coping behavior constitutes a water portfolio that consists of diversified resources that can be drawn on as necessary under uncertain conditions. This portfolio may include stored water, private groundwater, tanker water, and bottled water. Customers' access to private water takes them further from governmental purview. As a result, public entities may know little about how their citizens obtain water, how much they pay, and how much they consume [40]. This complicates efforts to gather data, understand the system, and propose beneficial changes. As individual consumers assume more responsibility for their water, demonstrated in many of the Consumer Response conditions of Table 2, public suppliers are surrendering their control and monitoring capabilities.

These investments give consumers more control over their water supply, though it costs them in other ways - for example, in time, household space, and water quality. Privatizing costs means that public utilities lose revenue, even though water is available to the community (as evidenced by its being delivered to the consumer). This reduces the options for system improvement, even though costs of private investment can exceeds the cost of upgrading the level of service provided by the public systems $[15,38]$. The beneficiaries of this situation are the private water providers; the losers are the municipal providers and, in the aggregate, the consumers.

Intermittent water supply does not lead to equity, especially in unreliable systems: The issue of equity emerges frequently in examinations of intermittent water supply. Many of the conditions of intermittency, like low prices, broad network distribution, and rationing, are intended to deliver water as broadly and inclusively as possible. Recent research has calculated optimized distribution schedules for intermittent supply in an effort to support equanimity and justice [16,104]. However, studies have shown that poor communities within such systems shoulder many additional coping expenses, many of which are not visible to system operators [94,127]. When analyzing intermittent supply, additional data are often needed to determine whether the lower cost of intermittent water (compared to other sources such as bottled water or tanker water) offsets the coping mechanisms (including non-monetary) imposed on poor populations as they respond to system uncertainty. In some cases, implementing intermittent water may indeed provide a net benefit to all consumers. Unfortunately, system costs, including often-inequitably distributed inefficiencies, are largely hidden [5]. Even in arid regions where domestic water supply does not face absolute scarcity [134], shortages imply choices regarding allocation-whether among communities or in favor of other economic sectors, such as agriculture or industry. Alternatives to intermittent supply regimes exist as well, such as investing in water desalination capacity or raising prices for the limited supply available [135]. Studies have shown that users are willing to pay for improved domestic supply reliability [85,98,117,122,136,137].

Low consumer confidence affects a system's potential to improve: Willingness-to-pay studies have found that even the poor are willing to pay more for improved water reliability and access $[107,108,118]$. Consumers who receive the worst service may be most willing to pay for improvements [51], presumably because they are better acquainted with alternative coping costs. The problem with public water supply is often not that people cannot afford a full-service system [33], but that willingness to pay decreases when consumers are convinced that the service will not improve 
when they do pay $[87,120]$. We contend that such consumers are accustomed to a water system so unreliable that it has eroded their confidence, which we recognize may also be affected by factors external to intermittent supply, or water supply more generally. Short-term political interests, including corruption can create a reinforcing situation of low quality service and lack of public support. [138] Infrastructure is an important way in which people interact with and evaluate their government [139]. Water services in particular provide an opportunity to demonstrate the commitment and efficacy of their local authorities. Any interventions that require public buy-in, such as raising prices to enable infrastructural improvements, must simultaneously address issues of consumer confidence and trust.

All intermittency is expensive: The on-and-off nature of intermittency causes pipes to deteriorate faster [49] and these costs will eventually be borne by the community. Coping mechanisms for water rationing is expensive for consumers [53]. At the same time, non-revenue water can increase as a percentage of use even as the supplier's revenue declines. "The intermittent supply policy seems to have burdened the [water distributer] with additional loads and increased risk of failure" [34]. Furthermore, according to the World Health Organization, intermittent water supply should be assumed to be contaminated [140]. Given the high costs of water intermittency, we ask whether it makes more sense to invest in water management that continuously and reliably provides clean water in sufficient supply to all consumers by raising higher prices or other strategies.

These are all issues that emerge from a multi-disciplinary analysis, especially from the confluence of local governance, capacity constraint, and consumer response- the three most common categories of the conditions we identified. We propose that a basic reinforcing structure play a central role in connecting these three categories:

Consumers' disengagement from system $\rightarrow$ water managers not incentivized to enact good management $\rightarrow$ inadequate service provided $\rightarrow$ consumer disengagement from system.

However the cycle starts, it can become a self-justifying, self-reinforcing spiral of decline for all concerned. In response to statements from the president of the European Parliament regarding Israeli water policies affecting Palestinian consumers, Malcolm Lowe writes, " . . wastage of water from leaky pipes and plain theft of water are rampant ... A friend who just came back from a West Bank town reported hearing from the locals that there nobody pays water bills or even municipal taxes. This may have been boastful exaggeration, but it testifies to an attitude" [141]. This statement implies that, because Palestinian consumers are disengaged from the system, changes in Israel's management policies, e.g. correcting access inequality, are not justified, despite documented inequities between Israeli and Palestinian consumers within the same watersheds. Considering this from the perspective of the intermittency pathways in Table 2 (and most West Bank consumers receive water intermittently), the reasons presented-leaks, private connections, low (or non-) payment-are themselves consequences of a poor supply system. Consumers need to pay for good infrastructure, but it is a tough sell when there is documented inequity in service quality and water provision among different consumers. On both the managers' side and the consumers' side, there is a question of trust. Responsibility can thus appear to be dangerously diffuse, but as our analysis of the influence ratio suggests, improvements to address intermittency can start with changes in consumer practices and changes in policies.

Beyond increasing pricing and sourcing additional water supply, there are many available solutions for addressing intermittency. In Argentina, water privatization that had subsidies for the poor and allowed for profit and service shut-off for non-payments and led to better service for the poor [142]. These can including restructuring water tariffs, awareness programs, or a phase-out of agricultural subsidies [67]. Wutich et al. [126] examine ways that the informal water distribution economy can contribute to advancing the human right for water. Social, commercial and technical innovations can help extend the coverage and institutional creativity needed for future growth [143]. Decentralized planning may reach more people and distribute power to lower levels for creative, innovative and responsive provision programs [144], although others suggest that community management can shift perceptions of responsibility to the more visible local figures [145]. 
On a larger scale, Vaidya [146] examines governance and management of local storage to support community resilience.

Understanding the pathways between conditions of water supply intermittency makes interdisciplinary analysis all the more important, because what may appear to be engineering constraints may actually be governance or management constraints. The conditions need to be understood as a structure to characterize the whole system and demonstrate that decisions or actions in one arena can effect options in another. Accounting for this structure can facilitate implementing water access improvements through multiple interventions. More research is needed to demonstrate which interventions are most appropriate in the different intermittency conditions.

\section{Limitations}

This study used examined pathways between intermittent water supply conditions to identify influential conditions. However, we were unable to add weights to the various pathways and conditions. Viewing some conditions and pathways as stronger or more durable than others could significantly change the options for intervention. However, as we had no methodology to evaluate possible weights, we set them all as equal for the ratio analysis. Additionally, the distinctions between the various conditions are not clearly defined in the literature, thus requiring us to make subjective judgments about which conditions could be combined and which could stand on their own.

\section{Conclusions}

Because water supply is basic to human security, water access has been defined as a human right. Though intermittent systems can offer short-term benefits-such as rationing scarce supplies-human drivers within the system can create reinforcing structures that may cause intermittency to continue even when sufficient water is available. Water intermittency, particularly when complicated by unreliable supply, jeopardizes communities' access to water. It is an issue that encompasses politics, engineering, human health, and social norms. Interdisciplinary studies are needed to better characterize the broader context of intermittent supply's impacts.

In an effort to demonstrate the human-related drivers that reinforce water system intermittency and can be targeted for interventions, this critical literature review identified 47 conditions of intermittent water supply and the causal-consequential pathway among them. Using ratios to identify influential conditions, the analysis showed the importance of demand-side interventions in policies and consumer behavior. Our analysis revealed a gap in the literature regarding different types of intermittent water and their varying costs to each actor in a given water distribution system. In particular, the literature emphasizes that as water access becomes less reliable, the consequences for the consumer become more problematic. Therefore, it is particularly important to use standardized language to describe each case under investigation. Understanding these conditions will allow better contextualization of case studies and enhance shared learning among them. Managers have many options for providing consumers with continuous—or at least reliable-water access. The benefits of a functioning and sustainable public system will accrue over time to both municipal suppliers and consumers, contributing to water security and stability.

Acknowledgments: This study received funding from the Office of the Provost at Tufts University. The study also received support from the Stockholm Environment Institute and, in particular, advice and guidance from Vishal Mehta of SEI. Open access costs were provided by Tufts University Faculty Research Awards Committee Open Access Funds.

Author Contributions: Stephanie Galaitsi and Jennifer Bogle produced the initial version this paper, after which Galaitsi substantially expanded the scope and formulated and conducted the analysis. Rusty Russell, Amahl Bishara, Annette Huber-Lee and John Durant redirected portions of the analysis, refined the terminology proposed in the discussion, and assisted with the writing. Russell mapped the restructuring of the paper following an initial review and Bishara also assisted with the interdisciplinary analysis.

Conflicts of Interest: The authors declare no conflict of interest. 


\section{References}

1. Zérah, M.-H. How to assess the quality dimension of urban infrastructure: The case of water supply in Delhi. Cities 1998, 15, 285-290.

2. Ingeduld, P.P.A.; Svitak, Z.T.A. Modelling intermittent water supply systems with EPANET. In Proceedings of the Water Distribution Systems Analysis Symposium 2006, Cincinnati, OH, USA, 27-30 August 2006; pp. 1-8.

3. Subbaraman, R.; Nolan, L.; Sawant, K.; Shitole, S.; Shitole, T.; Nanarkar, M.; Patil-Deshmukh, A.; Bloom, D.E. Multidimensional measurement of household water poverty in a Mumbai slum: Looking beyond water quality. PLoS ONE 2015, 10, e0133241.

4. Katuwal, H.; Bohara, A. Coping with poor water supplies: Empirical evidence from Kathmandu, Nepal. J. Water Health 2011, 9, 143-158.

5. Baisa, B.; Davis, L.W.; Salant, S.W.; Wilcox, W. The welfare costs of unreliable water service. J. Dev. Econ. 2010, 92, 1-12.

6. Klingel, P. Technical causes and impacts of intermittent water distribution. Water Sci. Technol. Water Supply 2012, 12, 504-512.

7. De Marchis, M.; Fontanazza, C.; Freni, G.; La Loggia, G.; Napoli, E.; Notaro, V. Analysis of the impact of intermittent distribution by modelling the network-filling process. J. Hydroinform. 2011, 13, 358-373.

8. Manohar, U.; Kumar, M.M. Modeling Equitable Distribution of Water: Dynamic Inversion-Based Controller Approach. J. Water Resour. Plan. Manag. 2013, 140, 607-619.

9. Amr, S.A.; Yassin, M.M. Microbial contamination of the drinking water distribution system and its impact on human health in Khan Yunis Governorate, Gaza Strip: Seven years of monitoring (2000-2006). Public Health 2008, 122, 1275-1283.

10. Abu-Madi, M.; Trifunovic, N. Impacts of supply duration on the design and performance of intermittent water distribution systems in the West Bank. Water Int. 2013, 38, 263-282.

11. Aguilar, A.G.; López, F.M. Water Insecurity among the urban poor in the peri-urban zone of Xochimilco, México City. J. Lat. Am. Geogr. 2009, 8, 97-123.

12. Akram, A.A.; Olmstead, S.M. The value of household water service quality in Lahore, Pakistan. Environ. Resour. Econ. 2011, 49, 173-198.

13. Al-Ghamdi, A. Leakage-pressure relationship and leakage detection in intermittent water distribution systems. J. Water Supply Res. Technol. 2011, 60, 178-183.

14. Alhassan, H.; Kwakwa, P.A. When water is scarce: The perception of water quality and effects on the vulnerable. J. Water Sanit. Hyg. Dev. 2014, 4, 43-50.

15. Altaf, M.A. The economics of household response to inadequate water supplies: Evidence from Pakistan. Third World Plan. Rev. UK 1994, 16. [CrossRef]

16. Effah, A.E.; Ali, M.F.; Josef, B. Improving equity in intermittent water supply systems. J. Water Supply Res. Technol.-AQUA 2013, 62. [CrossRef]

17. Andey, S.P.; Kelkar, P.S. Influence of intermittent and continuous modes of water supply on domestic water consumption. Water Resour. Manag. 2009, 23, 2555-2566.

18. Andey, S.P.; Kelkar, P.S. Performance of water distribution systems during intermittent versus continuous water supply. J. Am. Water Works Assoc. 2007, 99-106.

19. Arnold, M.; VanDerslice, J.A.; Taylor, B.; Benson, S.; Allen, S.; Johnson, M.; Kiefer, J.; Boakye, I.; Arhinn, B.; Crookston, B.T. Drinking water quality and source reliability in rural Ashanti region, Ghana. J. Water Health 2013, 11, 161-172.

20. Arouna, A.; Dabbert, S. Estimating rural households' willingness to pay for water supply improvements: A Benin case study using a semi-nonparametric bivariate probit approach. Water Int. 2012, 37, 293-304.

21. Ayoub, G.M.; Malaeb, L. Impact of intermittent water supply on water quality in Lebanon. Int. J. Environ. Pollut. 2006, 26, 379-397.

22. Bari, M.; Miah, M.; Awall, M.; Hossain, M.; Rashid, M.H.; Sarker, D.C. Availability of Water for Domestic Purposes in Dhaka Division. In IABSE Symposium Report; International Association for Bridge and Structural Engineering: Zurich, Switzerland, 2005; Volume 89, pp. 567-573. 
23. Batish, R. A New Approach to the Design of Intermittent Water Supply Networks. In World Water $\mathcal{E}$ Environmental Resources Congress 2003; American Society of Civil Engineers: Philadelphia, PA, USA, 2003; pp. 1-11.

24. Biggs, E.M.; Duncan, J.M.; Atkinson, P.M.; Dash, J. Plenty of water, not enough strategy: How inadequate accessibility, poor governance and a volatile government can tip the balance against ensuring water security: The case of Nepal. Environ. Sci. Policy 2013, 33, 388-394.

25. Biswas, P.; Mandal, K. Drinking Water in Rural India: A Study on Deficiency, Quality and Some Social Implications. Water Policy 2010, 12, 885-897.

26. Boelens, R.; Budds, J.; Bury, J.; Butler, C.; Crow, B.; Dill, B.; French, A.; Harris, L.M.; Hoag, C.; Kulkarni, S.; et al. Santa Cruz declaration on the global water crisis. Water Int. 2014, 39, 246-261.

27. Bontianti, A.; Hungerford, H.; Younsa, H.H.; Noma, A. Fluid experiences: Comparing local adaptations to water inaccessibility in two disadvantaged neighborhoods in Niamey, Niger. Habitat Int. 2014, 43, $283-292$.

28. Bradley, D.J.; Bartram, J.K. Domestic water and sanitation as water security: Monitoring, concepts and strategy. Philos. Trans. R. Soc. Lond. Math. Phys. Eng. Sci. 2013, 371, 20120420.

29. Bradley, R.M.; Weeraratne, S.; Mediwake, T.M. International issues-Water use projections in developing countries-Careful evaluation of actual water use patterns is critical to planning efficient and well-used water delivery systems in. Am. Water Works Assoc. J. 2002, 94, 52-63.

30. Cabrera-Bejar, J.A.; Tzatchkov, V.G. Inexpensive modeling of intermittent service water distribution networks. In Proceedings of the EWRI-ASCE World Environmental \& Water Resources Congress, Kansas City, MO, USA, 17 May 2009; Volume 21.

31. Caprara, A.; de Lima, J.W.O.; Marinho, A.C.P.; Calvasina, P.G.; Landim, L.P.; Sommerfeld, J. Irregular water supply, household usage and dengue: A bio-social study in the Brazilian Northeast. Cad. Saúde Pública 2009, 25, S125-S136.

32. Chandapillai, J.; Sudheer, K.P.; Saseendran, S. Design of water distribution network for equitable supply. Water Resour. Manag. 2012, 26, 391-406.

33. Choe, K.; Varley, R.C.; Bijlani, H.U. Coping with intermittent water supply: Problems and prospects. In Activity Report; Environmental Health Project: Dehra Dun, India, 1996.

34. Christodoulou, S.; Agathokleous, A. A study on the effects of intermittent water supply on the vulnerability of urban water distribution networks. Water Sci. Technol. Water Supply 2012, 12, 523-530.

35. Coelho, S.; James, S.; Sunna, N.; Chatila, J. Controlling water quality in intermittent supply systems. Water Supply 2003, 3, 119-125.

36. Criminisi, A.; Fontanazza, C.M.; Freni, G.; La Loggia, G. Evaluation of the apparent losses caused by water meter under-registration in intermittent water supply. Water Sci. Technol. 2009, 60, 2373.

37. Cubillo, F. Droughts, risk management and reliability. Water Sci. Technol. Water Supply 2004, 4, 1-11.

38. Dauda, S.A.; Yacob, M.R.; Radam, A. Household's willingness to pay for heterogeneous attributes of drinking water quality and services improvement: An application of choice experiment. Appl. Water Sci. 2015, 5, 253-259.

39. De Marchis, M.; Fontanazza, C.M.; Freni, G.; La Loggia, G.; Napoli, E.; Notaro, V. A model of the filling process of an intermittent distribution network. Urban Water J. 2010, 7, 321-333.

40. De Marchis, M.; Milici, B.; Freni, G. Pressure-Discharge Law of Local Tanks Connected to a Water Distribution Network: Experimental and Mathematical Results. Water 2015, 7, 4701-4723.

41. De Marchis, M.; Fontanazza, C.M.; Freni, G.; La Loggia, G.; Notaro, V.; Puleo, V. A mathematical model to evaluate apparent losses due to meter under-registration in intermittent water distribution networks. Water Sci. Technol. Water Supply 2013, 13, 914-923.

42. Dutta, V.; Tiwari, A.P. Cost of services and willingness to pay for reliable urban water supply: A study from Delhi, India. Water Sci. Technol. Water Supply 2005, 5, 135.

43. Elala, D.; Labhasetwar, P.; Tyrrel, S.F. Deterioration in water quality from supply chain to household and appropriate storage in the context of intermittent water supplies. Water Sci. Technol. Water Supply 2011, 11, 400-408.

44. Ennis-McMillan, M.C. Suffering from water: Social origins of bodily distress in a Mexican community. Med. Anthropol. Q. 2001, 15, 368-390. 
45. Ercumen, A.; Arnold, B.F.; Kumpel, E.; Burt, Z.; Ray, I.; Nelson, K.; Colford, J.M., Jr. Upgrading a Piped Water Supply from Intermittent to Continuous Delivery and Association with Waterborne Illness: A Matched Cohort Study in Urban India. PLoS Med. 2015, 12, e1001892.

46. Evison, L.; Sunna, N. Microbial regrowth in household water storage tanks. Am. Water Works Assoc. 2001, 93, 85-94.

47. Fan, L.; Liu, G.; Wang, F.; Ritsema, C.J.; Geissen, V. Domestic Water Consumption under Intermittent and Continuous Modes of Water Supply. Water Resour. Manag. 2014, 28, 853-865.

48. Fontanazza, C.M.; Freni, G.; La Loggia, G. Analysis of intermittent supply systems in water scarcity conditions and evaluation of the resource distribution equity indices. WIT Trans. Ecol. Environ. 2007, 103, 635-644.

49. Freni, G.; De Marchis, M.; Napoli, E. Implementation of pressure reduction valves in a dynamic water distribution numerical model to control the inequality in water supply. J. Hydroinform. 2014, 16, 207-217.

50. Galaitsi, S.E.; Huber-Lee, A.; Vogel, R.M.; Naumova, E.N. Using water insecurity to predict domestic water demand in the Palestinian West Bank. Water Int. 2015, 40, 614-634.

51. Genius, M.; Tsagarakis, K.P. Water shortages and implied water quality: A contingent valuation study. Water Resour. Res. 2006, 42. [CrossRef]

52. Goyal, R.V.; Patel, H.M. Analysis of residual chlorine in simple drinking water distribution system with intermittent water supply. Appl. Water Sci. 2015, 5, 311-319.

53. Habi, M.; Harrouz, O. Domestic water conservation practices in Tlemcen City (Algeria). Appl. Water Sci. 2015, 5, 161-169.

54. Haddadin, M.J. Water Resources in Jordan: Evolving Policies for Development, the Environment, and Conflict Resolution; Resources for the Future: Washington, DC, USA, 2006.

55. Hashwa, F.; Tokajian, S. Intermittent Water Supply and Domestic Water Quality in the Middle East. In Water in the Middle East and in North Africa; Springer: New York, NY, USA, 2004; pp. 157-166.

56. Hensher, D.; Shore, N.; Train, K. Households' willingness to pay for water service attributes. Environ. Resour. Econ. 2005, 32, 509-531.

57. Howard, G.; Bartram, J. Domestic Water Quantity, Service Level, and Health; World Health Organization: Geneva, Swizerland, 2003.

58. Howe, C.W.; Smith, M.G.; Bennett, L.; Brendecke, C.M.; Flack, J.E.; Hamm, R.M.; Mann, R.; Rozaklis, L.; Wunderlich, K. The value of water supply reliability in urban water systems. J. Environ. Econ. Manag. 1994, 26, 19-30.

59. Huang, L.-Y.; Wang, Y.-C.; Liu, C.-M.; Wu, T.-N.; Chou, C.-H.; Sung, F.-C.; Wu, C.-C. Water outage increases the risk of gastroenteritis and eyes and skin diseases. BMC Public Health 2011, 11, 726.

60. Humplick, F.; Kudat, A.; Madanat, S. Household Response to Reliability of Water Supply: The Case of Istanbul, Turkey; Policy Planning and Research Staff, The World Bank: Washington, DC, USA, 1992.

61. Humplick, F.; Kudat, A.; Madanat, S. Modeling Household Responses to Water Supply: A Service Quality Approach; Banque Mondiale, Transportation, Water, and Urban Development Department: Washington, DC, USA, 1993.

62. Hunter, P.R.; Zmirou-Navier, D.; Hartemann, P. Estimating the impact on health of poor reliability of drinking water interventions in developing countries. Sci. Total Environ. 2009, 407, 2621-2624.

63. Jensen, P.K.; Ensink, J.H.; Jayasinghe, G.; Van Der Hoek, W.; Cairncross, S.; Dalsgaard, A. Domestic transmission routes of pathogens: The problem of in-house contamination of drinking water during storage in developing countries. Trop. Med. Int. Health 2002, 7, 604-609.

64. Jepson, W. Measuring "no-win" waterscapes: Experience-based scales and classification approaches to assess household water security in colonias on the US-Mexico border. Geoforum 2014, 51, 107-120.

65. Jepson, W.; Vandewalle, E. Household Water Insecurity in the Global North: A Study of Rural and Periurban Settlements on the Texas-Mexico Border. Prof. Geogr. 2016, 68, 66-81.

66. Kansal, M.L.; Kumar, A.; Sharma, P.B. Reliability analysis of water distribution systems under uncertainty. Reliab. Eng. Syst. Saf. 1995, 50, 51-59.

67. Klassert, C.; Sigel, K.; Gawel, E.; Klauer, B. Modeling Residential Water Consumption in Amman: The Role of Intermittency, Storage, and Pricing for Piped and Tanker Water. Water 2015, 7, 3643-3670.

68. Klingel, P.; Nestmann, F. From intermittent to continuous water distribution: A proposed conceptual approach and a case study of Béni Abbès (Algeria). Urban Water J. 2014, 11, 240-251. 
69. Korfali, S.I.; Jurdi, M. Assessment of domestic water quality: Case study, Beirut, Lebanon. Environ. Monit. Assess. 2007, 135, 241-251.

70. Kumar, A. Leakage control in intermittent water supplies. Water Supply Rev. J. Int. Water Supply Assoc. 1997, 5, 55-58.

71. Kumar, A. Technologies to improve efficiency in distribution system with intermittent supplies. Water Supply Int. Water Supply Assoc. 1998, 16, 576-579.

72. Kumar, M.M.; Manohar, U.; Pallavi, M.R.M.; Anjana, G.R. Urban water supply and management. J. Indian Inst. Sci. 2013, 93, 295-318.

73. Kumpel, E.; Nelson, K.L. Comparing microbial water quality in an intermittent and continuous piped water supply. Water Res. 2013, 47, 5176-5188.

74. Kumpel, E.; Nelson, K.L. Mechanisms affecting water quality in an intermittent piped water supply. Environ. Sci. Technol. 2014, 48, 2766-2775.

75. Kumpel, E.; Nelson, K.L. Intermittent Water Supply: Prevalence, Practice, and Microbial Water Quality. Environ. Sci. Technol. 2016, 50, 542-553.

76. Lee, E.; Schwab, K. Deficiencies in drinking water distribution systems in developing countries. J. Water Health 2005, 3, 109-127.

77. Majuru, B.M.M.M.; Jagals, P.H.P.R. Health impacts of small-community water supply reliability. International Journal of Hygiene and Environmental Health. Int. J. Hyg. Environ. Health 2011, 214, 162-166.

78. Majuru, B.; Jagals, P.; Hunter, P.R. Assessing rural small community water supply in Limpopo, South Africa: Water service benchmarks and reliability. Sci. Total Environ. 2012, 435, 479-486.

79. Mason, L.R. Gender and asset dimensions of seasonal water insecurity in urban Philippines. Weather Clim. Soc. 2012, 4, 20-33.

80. Matsinhe, N.P.; Juizo, J.; Persson, K.M. The Effect of Intermittent Supply and Household Storage on the Quality of Drinking Water in Maputo. Available online: http://www.tidskriftenvatten.se/mag/ tidskriftenvatten.se/dircode/docs/48_article_4739.pdf (accessed on 24 June 2016).

81. McIntosh, A.C. Asian Water Supplies Reaching the Urban Poor. 2003. Available online: https://openaccess. adb.org/handle/11540/264 (accessed on 24 June 2016).

82. Mehta, L. Whose scarcity? Whose property? The case of water in western India. Land Use Policy 2007, 24, 654-663.

83. Mermin, J.H.; Villar, R.; Carpenter, J.; Roberts, L.; Gasanova, L.; Lomakina, S.; Bopp, C.; Hutwagner, L.; Mead, P.; Ross, B.; et al. A massive epidemic of multidrug-resistant typhoid fever in Tajikistan associated with consumption of municipal water. J. Infect. Dis. 1999, 179, 1416-1422.

84. Mier, M.V.; Callejas, R.L.; Rodriguez, J.F.; Gonzalez, A. Inadequate water supply and environmental quality deterioration in an irregular settlement. In Environmental Engineering and Health Sciences; Proceedings of the International Symposium on Environmental Engineering and Health Sciences: A Joint Effort for the XXI Century, Cholula, Puebla, Mexico, 26-30 October 1998; Universidad de Las Americas-Puebla; Water Resources Publication: Englewood, CO, USA, 2000; p. 145.

85. Moffat, B.; Motlaleng, G.R.; Thukuza, A. Households willingness to pay for improved water quality and reliability of supply in Chobe ward, Maun. Botsw. J. Econ. 2011, 8, 45-61.

86. Mohapatra, S.; Sargaonkar, A.; Labhasetwar, P.K. Distribution network assessment using EPANET for intermittent and continuous water supply. Water Resour. Manag. 2014, 28, 3745-3759.

87. Myers, S. Water and Sanitation Program. $24 \mathrm{~h}$ Water Supply: Is this Goal Achievable? Drawing lessons from rapid distribution system diagnostic assessments in Indian cities. In Proceedings of the Fifteenth Meeting of the Urban Think Tank, Hyderabad, India, 23-24 September 2003.

88. Nganyanyuka, K.; Martinez, J.; Wesselink, A.; Lungo, J.H.; Georgiadou, Y. Accessing water services in Dar es Salaam: Are we counting what counts? Habitat Int. 2014, 44, 358-366.

89. Nygaard, K.; Wahl, E.; Krogh, T.; Tveit, O.A.; Bøhleng, E.; Tverdal, A.; Aavitsland, P. Breaks and maintenance work in the water distribution systems and gastrointestinal illness: A cohort study. Int. J. Epidemiol. 2007, 36, 873-880.

90. Okotto, L.; Okotto-Okotto, J.; Price, H.; Pedley, S.; Wright, J. Socio-economic aspects of domestic groundwater consumption, vending and use in Kisumu, Kenya. Appl. Geogr. 2015, 58, 189-197.

91. Olmstead, S.M. Water supply and poor communities: What's price got to do with it? Environ. Sci. Policy Sustain. Dev. 2003, 45, 22-35. 
92. O'Neill, J.A. Upgrading an Intermittent E Branched Water Network to a Continuous E Looped Network: A Case Study in Coastal Peru; Master's report; Michigan Technological University: Houghton, MI, USA, 2012.

93. Ostfeld, A. Reliability analysis of regional water distribution systems. Urban Water 2001, 3, 253-260.

94. Pattanayak, S.K.; Yang, J.-C.; Whittington, D.; Bal Kumar, K.C. Coping with unreliable public water supplies: Averting expenditures by households in Kathmandu, Nepal. Water Resour. Res. 2005, 41. [CrossRef]

95. Pierce, G.; Jimenez, S. Unreliable Water Access in US Mobile Homes: Evidence From the American Housing Survey. Hous. Policy Debate 2015, 25, 739-753.

96. Prakash, A.; Sama, R.K. Social undercurrents in a water-scarce village. Econ. Polit. Wkly. 2006, 577-579.

97. Rahman, A.; Lee, H.K.; Khan, M.A. Domestic water contamination in rapidly growing megacities of Asia: Case of Karachi, Pakistan. Environ. Monit. Assess. 1997, 44, 339-360.

98. Rananga, H.T.; Gumbo, J.R. Willingness to Pay for Water Services in Two Communities of Mutale Local Municipality, South Africa: A Case Study. J. Hum. Ecol. 2015, 49, 231-243.

99. Rosenberg, D.E.; Talozi, S.; Lund, J.R. Intermittent water supplies: Challenges and opportunities for residential water users in Jordan. Water Int. 2008, 33, 488-504.

100. Rosenberg, D.E.; Tarawneh, T.; Abdel-Khaleq, R.; Lund, J.R. Modeling integrated water user decisions in intermittent supply systems. Water Resour. Res. 2007, 43. [CrossRef]

101. Sashikumar, N.; Mohankumar, M.S.; Sridharan, K. Modelling an intermittent water supply. In Proceedings of the World Water and Environmental Resources Congress 2003, Philadelphia, PA, USA, 23-26 June 2003; p. 261.

102. Sethi, K. Household's Responses to Unreliable Water Supply in Jamshedpur, India: A Report; Transport, Water and Urban Development Department, The World Bank: Washington, DC, USA, 1992.

103. Sijbesma, C.; Verhagen, J.; Nanavaty, R.; James, A.J. Impacts of domestic water supply on gender and income: Results from a participatory study in a drought-prone region in Gujarat, India. Water Policy 2009, 11, 95-105.

104. Solgi, M.; Bozorg Haddad, O.; Seifollahi-Aghmiuni, S.; Loáiciga, H.A. Intermittent operation of water distribution networks considering equanimity and justice principles. J. Pipeline Syst. Eng. Pract. 2015, 6, 4015004.

105. Soltanjalili, M.-J.; Bozorg Haddad, O.; Mariño, M.A. Operating water distribution networks during water shortage conditions using hedging and intermittent water supply concepts. J. Water Resour. Plan. Manag. 2013, 139, 644-659.

106. Stevenson, E.G.; Greene, L.E.; Maes, K.C.; Ambelu, A.; Tesfaye, Y.A.; Rheingans, R.; Hadley, C. Water insecurity in 3 dimensions: An anthropological perspective on water and women's psychosocial distress in Ethiopia. Soc. Sci. Med. 2012, 75, 392-400.

107. Stoler, J.; Fink, G.; Weeks, J.R.; Otoo, R.A.; Ampofo, J.A.; Hill, A.G. When urban taps run dry: Sachet water consumption and health effects in low income neighborhoods of Accra, Ghana. Health Place 2012, 18, 250-262.

108. Subbaraman, R.; Shitole, S.; Shitole, T.; Sawant, K.; O’Brien, J.; Bloom, D.E.; Patil-Deshmukh, A. The social ecology of water in a Mumbai slum: Failures in water quality, quantity, and reliability. BMC Public Health 2013, 13, 173.

109. Sultana, F. Suffering for water, suffering from water: Emotional geographies of resource access, control and conflict. Geoforum 2011, 42, 163-172.

110. Tokajian, S.; Hashwa, F. Water quality problems associated with intermittent water supply. Water Sci. Technol. 2003, 47, 229-234.

111. Totsuka, N.; Trifunovic, N.; Vairavamoorthy, K. Intermittent urban water supply under water starving situations. In Proceedings of the 30th WEDC International Conference on People-Centered Approaches to Water and Environmental Sanitation, Vientiane, Laos, 25-29 October 2004.

112. Tzatchkov, V.G.; Aldama, A.A.; Arreguin, F.I.; Buchberger, S.G.; Lee, Y.-H. Advection-dispersion transport in water distribution networks with intermittent flow. Water Resour. Manag. 2001, 48, 217-226.

113. Vairavamoorthy, K.; Gorantiwar, S.D.; Mohan, S. Intermittent water supply under water scarcity situations. Water Int. 2007, 32, 121-132.

114. Vairavamoorthy, K.; Gorantiwar, S.D.; Pathirana, A. Managing urban water supplies in developing countries-Climate change and water scarcity scenarios. Phys. Chem. Earth A B C 2008, 33, 330-339.

115. Vásquez, W.F. Nonpayment of water bills in Guatemala: Dissatisfaction or inability to pay? Water Resour. Res. 2015, 51, 8806-8816. 
116. Vásquez, W.F. Reliability perceptions and water storage expenditures: Evidence from Nicaragua. Water Resour. Res. 2012, 48. [CrossRef]

117. Vásquez, W.F.; Espaillat, R. Willingness to pay for reliable supplies of safe drinking water in Guatemala: A referendum contingent valuation study. Urban Water J. 2016, 13, 284-292.

118. Vásquez, W.F.; Franceschi, D. System reliability and water service decentralization: Investigating household preferences in Nicaragua. Water Resour. Manag. 2013, 27, 4913-4926.

119. Vásquez, W.F. A validity assessment of consumer satisfaction to measure performance of water services in Guatemala. J. Water Sanit. Hyg. Dev. 2015, 5, 301-309.

120. Virjee, K.; Gaskin, S. Coping with poor water services and the demand for change in Trinidad and Tobago. Water Int. 2010, 35, 285-297.

121. Wedgworth, J.C.; Brown, J.; Johnson, P.; Olson, J.B.; Elliott, M.; Forehand, R.; Stauber, C.E. Associations between perceptions of drinking water service delivery and measured drinking water quality in rural Alabama. Int. J. Environ. Res. Public. Health 2014, 11, 7376-7392.

122. Whittington, D.; Lauria, D.T.; Mu, X. A study of water vending and willingness to pay for water in Onitsha, Nigeria. World Dev. 1991, 19, 179-198.

123. Whittington, D. Behavioural studies of the domestic demand for water services in Africa: A reply to Stephen Merrett. Water Policy 2002, 4, 83-88.

124. Wutich, A. Water scarcity and the sustainability of a common pool resource institution in the urban Andes. Hum. Ecol. 2009, 37, 179-192.

125. Wutich, A.; Ragsdale, K. Water insecurity and emotional distress: Coping with supply, access, and seasonal variability of water in a Bolivian squatter settlement. Soc. Sci. Med. 2008, 67, 2116-2125.

126. Wutich, A.; Beresford, M.; Carvajal, C. Can Informal Water Vendors Deliver on the Promise of A Human Right to Water? Results From Cochabamba, Bolivia. World Dev. 2016, 79, 14-24.

127. Yepes, G.; Ringskog, K.; Sarkar, S. The high costs of intermittent water service. J. Indian Waterworks Assoc. 2001, 33, 167-170.

128. Zérah, M.-H. Water: Unreliable Supply in Delhi, Centre de Sciences Humaines; Manohar Publishers \& Distributors: New Delhi, India, 2000.

129. Zérah, M.-H. Household strategies for coping with unreliable water supplies: The case of Delhi. Habitat Int. 2000, 24, 295-307.

130. Cheng, D. Contestations at the last mile: The corporate-community delivery of water in Manila. Geoforum 2015, 59, 240-247.

131. Selby, J. Cooperation, domination and colonisation: The Israeli-Palestinian joint water committee. Water Altern. 2013, 6, 1-24.

132. Borgardi, J.J.; Dudgeon, D.; Lawford, R.; Flinkerbusch, E.; Meyn, A.; Pahl-wostl, C.; Vielhauer, K.; Vörösmarty, C. Water security for a planet under pressure: Interconnected challenges of a changing world call for sustainable solutions. Curr. Opin. Environ. Sustain. 2011, 4, 1-9.

133. United Nations Sustainable Development Goals: 17 Goals to Transform Our World. N.D. Available online: http:/ / www.un.org/sustainabledevelopment/sustainable-development-goals (accessed on 26 June 2016).

134. Allan, T. The Middle East Water Question: Hydropolitics and the Global Economy. Arab Stud. J. 2002, 9/10, 160-164.

135. Fisher, F.; Huber-Lee, A. Liquid Assets: An Economic Approach for Water Management and Conflict Resolution in the Middle East and Beyond; Routledge: Washington, DC, USA, 2012.

136. Lund, J.R. Derived estimation of willingness to pay to avoid probabilistic shortage. Water Resour. Res. 1995, 31, 1367-1372.

137. Griffin, R.C.; Mjelde, J.W. Valuing water supply reliability. Am. J. Agric. Econ. 2000, 82, 414-426.

138. Savedoff, W.D.; Spiller, P.T. Spilled Water: Institutional Commitment in the Provision of Water Services; Inter-American Development Bank (IDB): Washington, DC, USA, 1999.

139. Larkin, B. The politics and poetics of infrastructure. Annu. Rev. Anthropol. 2013, 42, 327-343.

140. WHO. How to Measure Chlorine Residual in Water; Technical Note \# 11; WHO: Leicestershire, UK, 2005.

141. Lowe, M. Palestinian Water (And Martin Schulz): The Lack of Logic. Available online: http://www. gatestoneinstitute.org/4198/israel-palestinian-water-martin-schulz (accessed on 24 June 2016).

142. Galiani, S.; Gertler, P.; Schargrodsky, E. Water for life: The impact of the privatization of water services on child mortality. J. Polit. Econ. 2005, 113, 83-120. 
143. Criqui, L. Infrastructure urbanism: Roadmaps for servicing unplanned urbanisation in emerging cities. Habitat Int. 2015, 47, 93-102.

144. Cherunya, P.C.; Janezic, C.; Leuchner, M. Sustainable Supply of Safe Drinking Water for Underserved Households in Kenya: Investigating the Viability of Decentralized Solutions. Water 2015, 7, 5437-5457.

145. Cheng, C.-L. Study of the inter-relationship between water use and energy conservation for a building. Energy Build. 2002, 34, 261-266.

146. Vaidya, R.A. Governance and management of local water storage in the Hindu Kush Himalayas. Int. J. Water Resour. Dev. 2015, 31, 253-268.

(C) 2016 by the authors; licensee MDPI, Basel, Switzerland. This article is an open access article distributed under the terms and conditions of the Creative Commons Attribution (CC-BY) license (http://creativecommons.org/licenses/by/4.0/). 